\section{Intersections}

Canadian Journal of Music

Revue canadienne de musique
Intersections CANADIAN JOURAL OF MUSIC
REVUE CANADIENEE DE MUSIOUH

\title{
Gender, Genre and Electroacoustic Soundmaking Practices
}

\section{Andra McCartney}

Volume 26, numéro 2, 2006

In and Out of the Sound Studio

URI : https://id.erudit.org/iderudit/1013224ar

DOI : https://doi.org/10.7202/1013224ar

Aller au sommaire du numéro

\section{Éditeur(s)}

Canadian University Music Society / Société de musique des universités canadiennes

\section{ISSN}

1911-0146 (imprimé)

1918-512X (numérique)

Découvrir la revue

Citer cet article

McCartney, A. (2006). Gender, Genre and Electroacoustic Soundmaking Practices. Intersections, 26(2), 20-48. https://doi.org/10.7202/1013224ar

\section{Résumé de l'article}

Cet article est une exploration des rapports sociaux de genre (" genrification ») dans les différents types et pratiques de création sonore électroacoustique, étudiant les procédés de " genrification » du niveau de langage utilisé dans les premières catégorisations dichotomiques entre la musique concrète et l'elektronische Musik,puis se penchant sur les arguments apparentés portent sur l'abstraction, le contexte et le contrôle compositionnel que l'on retrouve dans les écrits des créateurs électroacoustiques tels Pierre Schaeffer, Pierre Boulez, Daphne Oram, Pauline Oliveros et plusieurs participants du projet Dedans/Dehors du studio. L'analyse de leurs pratiques et de leurs idées suggère différentes manières de conceptualiser les genres de l'électroacoustique, leurs pratiques connexes et les rôles des créateurs sonores contemporains en électroacoustique (compositeurs, artistes, producteurs, sonorisateurs, auditoires...), en examinant les potentialités des concepts de connaissance compréhensive et de pensée écologique, termes proposés par l'épistémologiste féministe Lorraine Code.
Copyright (C Canadian University Music Society / Société de musique des universités canadiennes, 2007
Ce document est protégé par la loi sur le droit d'auteur. L’utilisation des services d’Érudit (y compris la reproduction) est assujettie à sa politique d'utilisation que vous pouvez consulter en ligne.

https://apropos.erudit.org/fr/usagers/politique-dutilisation/ 


\title{
Gender, Genre and Electroacoustic Soundmaking
}

\section{Practices}

\author{
Andra McCartney
}

\section{MUSIQUE CONCRÈTE VS. ELEKTRONISCHE MUSIK:}

\section{A GENDERED DICHOTOMY?}

The concepts of musique concrète and elektronische Musik were created in opposition. Initially, composers at the first two electronic studios to open, the Studio d'Essai at Radiodiffusion-Télévision Française (RTF) in Paris, where the Groupe de recherche musicale (GRM) worked, and the electronic studio at Westdeutscher Rundfunk (WDR) in Cologne, were each antagonistic to the work of the other studio, describing it in derogatory terms. Pierre Schaeffer of RTF was skeptical about electronically-produced sound and defined the music he was making, musique concrète, as having direct contact with sonic material: ${ }^{1}$

Je me méfie des instruments nouveaux, ondes ou ondiolines, de ce que les allemands appellent pompeusement lelectronische Musik [sic]. Devant toute musique électrique jai la réaction de mon père violoniste, de ma mère chanteuse. Nous sommes des artisans. Mon Violon, ma voix, je les retrouve dans tout ce bazar en bois ... et dans mes trompes à vélos. Je cherche le contact direct avec la matière sonore, sans électrons interposés. (Schaeffer 1990, 26)

Schaeffer sets up a dichotomy between his music and that of the German studio in explicit terms. While his music is related to performance (my father the violinist, my mother the singer) through direct contact with known materials, he describes the other studio as only concerned with electrical waveforms, conceived as fundamentally different new instruments. By emphasizing personal relationships with his family, known sonic materials and existing instruments, he connects his ideas with stereotypically feminine concreteness, relationship, domesticity and subjectivity, and distances himself from stereotypically masculine abstraction, artificiality and objectivity.

How accurate was Schaeffer's definition of the other studio? Initially, the WDR studio did want to sever connections with a known sound world. They

1 I mistrust new instruments, waves or waveforms, what the Germans pompously call elektronische Musik. Before all electrical music I respond like my father the violinist, and my mother the singer. We are artisans. My violin, my voice, I meet them again in this bazaar of wood ... and in my truck horns. I seek direct contact with sonic materials, without electrons interposed. [All translations are the author's.] 
used the serial technique ${ }^{2}$ of composition employing simple sine tones produced by oscillators rather than recorded sounds to make elektronische Musik:

In electronic serial music ... everything to the last element of the single note is subjected to serial permutation ... Today, the physical magnification of a sound is known...as exact scientific data ... Talk of 'humanized' electronic sound may be left to unimaginative instrument makers. (Eimert and Stockhausen 1958, 8)

This definition of elektronische Musik by Herbert Eimert, one of the original practitioners, does not explicitly set up an opposition with the Paris studio. However, he implies another camp by talking about "humanized" electronic sound which is "unimaginative," and associated with the craft work of instrument making. Also, Eimert makes the strategic move of associating elektronische Musik with scientific knowledge, the ability to know the physical magnification of sound as exact data, or objective knowledge, a stereotypically masculine domain.

\section{A Generative Distinction?}

This artificial distinction between the two studios disappeared within a few years. Although his first pieces kept sound sources recognizable, Schaeffer soon began to manipulate the envelopes of sounds in the studio so that their sources became unidentifiable. Composers at the WDR studio began to use acoustic as well as electronic sources, and extended compositional technique beyond serialism. Nevertheless, conceptualisations of musique concrète as fundamentally different from, and inferior to electronic music, continued to structure the way the field of electroacoustic music developed. One example can be found in how particular pieces are discussed. In his description of why Stockhausen's Gesang der Jünglinge is not musique concrète, musicologist Robin Maconie responds particularly to Schaeffer's use of the personal pronoun:

Soon after Gesang der Jünglinge had acquired a reputation it was put about that since the work incorporates a boy's recorded voice it qualified as musique concrète ... one suspects that the label represents an attempt either to transfer some of the credit for Stockhausen's achievement or alternatively to reduce the work in public eyes to the level of a Parisian caprice ... it is positively misleading. The manner in which Stockhausen integrates vocal sound into the electronic fabric of the piece would never have been sanctioned by the school of Schaeffer ("mon violon, ma voix"), even if its members had been technically well enough informed to understand what he was doing. The qualities of intelligence and workmanship that made Schaeffer so keen to claim the work in retrospect as musique concrète, elevate Gesang to an altogether higher plane ... the focus on the boy's voice naturally draws

2 A definition of serialism: "For [the European serialists of the early 1950s] serialism was a compositional technique wherein every aspect of a composition-not only notes, but also loudness, timbre, duration, type of attack, and every other imaginable parameter of a sound-could be based on and derived from the same row, or series, thereby producing a kind of total structure wherein every detail was organized" (Chadabe 1997, 37). 
attention to the "message" content of the text, which ... tends to obscure awareness of the purely formal relationships of the electronic sounds. It did not inhibit audiences, nevertheless, from instinctively recognizing the potency and authority of Stockhausen's handling of the medium. (Maconie 1976, 98-99; Maconie's italics)

In his attempt to show how it is not musique concrète, Maconie distinguishes Stockhausen's work from that of Schaeffer and his colleagues, establishing a hierarchy. Maconie praises Stockhausen's work as potent and authoritative, qualities associated with masculine mastery. He is also described as intelligent, establishing purely formal relationships, associating his work with the formal qualities of absolute music. The reference to a higher plane establishes a hierarchy of intellect. In contrast, composers like Schaeffer who work with musique concrète are portrayed as capricious and technically ill-informed, characteristics also used to create denigrating stereotypes of femininity. In order to distinguish Stockhausen's work from that of Schaeffer, Maconie describes Stockhausen's work as exhibiting many attributes of objective knowledge: it has authority and potency, it is technically well-informed and intelligent. Its only flaw, in Maconie's view, is that it draws attention to the "message" content of the text, an aspect of the piece that refers to something beyond purely formal relationships. In contrast, Schaeffer's work is held to have no qualities of objectivity, while Maconie stresses his subjectivity through repetition and emphasis on the personal pronoun.

Maconie was not alone in his dismissal of Schaeffer's work. Pierre Boulez describes it in more graphic terms in a letter to John Cage: "I shall tell you that the experimental studio is more and more crap, and that Schaeffer is a pain in the arse; and that I hope I shall soon be working with Stockhausen at the electronic music studio of Radio-Cologne" (Nattiez 1993, 145). He is clearly frustrated with Schaeffer and his approach to music, and contrasts Schaeffer with Stockhausen. Elsewhere, Boulez describes an absence of direction of the sonic material in musique concrète as damaging to composition: ${ }^{3}$

On n’a pas pris garde à la question du matériel, pourtant primordiale dans une telle aventure; on y a supplée par une espèce de parade poétique, dans la ligne du collage surréaliste ... Cet art poétique dénué de foi a vieilli, cette absence de dirigisme dans la détermination de la matière sonore entraîne fatalement une anarchie préjudiciable à la composition. (Schaeffer 1967, 13-14)

Here, Boulez expresses his belief that "primordial" sound materials need to be controlled. His criticism could be construed as an invocation of what philosopher Genevieve Lloyd refers to as "the primary Pythagorean contrast between form and formlessness" $(1984,3)$. Boulez criticizes musique concrète as anarchic, a poetic parade without leadership. He finds the musique concrète approach to be inadequate, and fatally damaging to composition, which to him is

3 One did not consider the question of material, left primordial in such a venture; a poetic parade is substituted, a surrealist collage ... This poetic art stripped of faith has become obsolete, this absence of control in determining the sonic material brings about an anarchy detrimental to composition. 
fundamentally concerned with formal control over materials. In its association with (primordial) formlessness and (anarchic) chaos, musique concrète, as described by Boulez, is thus aligned with the feminine in the original Pythagorean table of opposites that structure Western thought. ${ }^{4}$

Henri Pousseur relates how the process of criticizing Schaeffer's methods actually clarifies Boulez's own approach to composition:

In criticizing Schaeffer's methods, Boulez showed me exactly what he wanted to do. He wanted to restructure the material so he could have complete control. He wanted to unify the germ, to unify the seed, to have everything grow from one idea, and to apply a very precise, a very structured type of elaboration. (Peyser 1976, 74)

While Boulez wanted to sever his connections with Schaeffer, it was thus through relational opposition with Schaeffer that Boulez defined his own compositional aesthetic. Although Boulez emphasized individual control, Pousseur's story reveals how Boulez defined his ideas through interaction with another, what feminist epistemologist Lorraine Code calls second personhood. While traditional approaches to epistemology have focused on the ability of an individual subject to know, Code draws on feminist theory to put forth the idea that knowledge is made through interaction with others, second persons (1991, 84).

The ideas of Pierre Boulez became more powerful when he took the position of director of the electroacoustic research institute, IRCAM. Here, Boulez could assert his aesthetic ideas in a powerful institutional forum, shaping through his exclusions what could count as electroacoustic music. According to Georgina Born, antagonism to the work of Pierre Schaeffer and other composers at GRM, and to the approach of musique concrète, influenced Boulez's later conception of IRCAM, which became a leading centre of electroacoustic music both in France and internationally.

IRCAM's approach has commonly been understood as involving a strong rejection or negation of GRM aesthetics and technology in line with Boulez's early critique, so that his antagonism toward the GRM has been seen as a prime motive for the emergent conception of IRCAM. Indeed ... techniques and technologies associated with musique concrète-tape recording,

4 This strategy of decrying another's work as formless and without structure is used in other situations as well, for example by Karlheinz Stockhausen to differentiate his work from the experimental music of John Cage. Stockhausen says "Collage is gluing together and seeing what happens ... In America the music that's most praised has done away with all musical subjects. Cage is the example of collage music where everything's just thrown in one pot and you see what happens" (Cott 1973, 190-191). Here, Stockhausen states that this process of collage "has done away with all musical subjects," implying that musical subjects reside only within the conscious mind of the composer. His use of the phrase "everything's just thrown in one pot" denies any structure within the music of Cage. His alternative to collage is "metacollage": Metacollage and integration mean ... really dealing with strong subjects and then trying to create balanced situations. (ibid. 192). In Stockhausen's view, then, the composer must have the role of mediator, to order and balance the sounds. In his hierarchy, indeterminate elements are controlled by a structural form determined only by the composer. 
analog electronics-were subject to an almost irrational neglect and indifference within IRCAM culture. (Born 1995, 77)

Boulez's hostility towards Schaeffer and his approach affected not only his own attitude and working practice, but also the conception and aesthetic orientation of a major electroacoustic institution under his control. As director of IRCAM, he clearly privileged scientific thinking in the production of objective knowledge:

The creator's intuition alone is powerless to provide a comprehensive translation of musical invention. It is thus necessary for him to collaborate with the scientific research worker in order to envision the distant future, to imagine less personal, and thus broader, solutions ... The musician must assimilate a certain scientific knowledge, making it an integral part of his creative imagination. (Boulez quoted in Born 1995, 1; my emphasis)

Boulez distinguishes the composer from the scientific researcher in (traditionally) gendered terms: the composer alone, without scientific knowledge, is intuitive, personal, powerless-all characteristics which are stereotypically associated with white Western women. Only an imagined collaboration with a scientific research worker allows less personal, broader solutions by looking toward the future. In order for the composer to give forward-thrusting power to his creative imagination, he must assimilate scientific knowledge. Boulez here wishes for a common language between scientists and musicians through an idealized integration of two highly-differentiated poles of intuition and scientific thinking, an equation in which control and science are clearly privileged.

Schaeffer and Boulez articulated different approaches towards control, abstraction and context, which affected their compositional aesthetics, and through their leadership of different electroacoustic institutions, also affected the kind of work that was possible in those institutions. These ideas continue to structure electroacoustic thought. I have argued elsewhere (McCartney 2000) that works which used recognizable recorded sounds in a form that acknowledged the materiality of those sounds continued to be marginalised within electroacoustic discourse throughout the late decades of the twentieth century, while works that used highly processed, manipulated and abstracted sounds in a composerdefined form were favoured throughout this period.

There were other approaches to control, abstraction and context being developed during the 1950s and 1960s, although many of these approaches were muted since their authors received little attention. In order to understand the contributions of these muted authors, I want to introduce two concepts elaborated by epistemologist Lorraine Code: empathetic knowledge and ecological thinking. Both of these ways of thinking emerge from Code's thesis that knowledge is never made individually, but always in dialogue with others, second persons who inform and inflect how knowledge is produced.

Code is critical of what she terms "spectator epistemologies," in which others are treated as objects, subject to manipulation, prediction and control (1995, 125). Unlike spectator epistemologies, empathy "resists closure, invites conversation, fosters and requires second-person relations. And empathy, moreover, is 
a self-reflexive skill. When it is well-developed, well practiced, it incorporates a capacity to assess its own aptness" (Code 1995, 126). Importantly, Code insists that empathy is not a natural characteristic of biological women. Rather, it is a skill, something that needs to be learned and practiced. Furthermore, and importantly for this essay, the concept of empathy originated in the ability to project oneself into an object of aesthetic contemplation, and its use in psychiatry has derived from this aesthetic skill. ${ }^{5}$ Here we return to think of the skill of empathetic knowing in its aesthetic dimension as well as that of the social.

Code's point of entry into ecological thinking is through the early work of biologist (and ecologist, in retrospect) Rachel Carson:

\begin{abstract}
Carson's investigations are both situated, and open: as ready to see what the world around her can reveal as to test her hunches and hypotheses against "reality". No formal methodology guides her inquiry, yet it is thoroughly methodical; nor has she the patience with the punctiform fact, the isolated epistemic moment; yet neither are her investigations and findings random or chaotic. $(2005,93)$
\end{abstract}

Carson studied detailed inter-relationships among organisms in specific habitats, searching for patterns, her method "alert for the unexpected: it seeks coherence but does not force it when differences, anomalies, contest its smoothness" (Code 2005, 93-94; my emphasis). She produced focused case studies, integrating narrative and anecdote with observation and analysis in the field. She did not consider cataloguing sufficient for understanding, needing to explore how these specificities work together. She understood that different sites required different methods, and adapted her thinking to the context. This is situated knowledge, in the way that Haraway (1991) uses that term. Knowledge is situated both by attempting to know the place of study as closely as possible, as well as to attempt to understand one's own epistemic position, its partialities and limitations, as clearly as one can, and to make that clear.

I will argue that some composers who were contemporaries of Boulez, as well as many more recent soundmakers such as some in our study, are practitioners of empathetic knowledge and ecological thinking. However, their contributions have not received the attention that they deserve, in an environment which remains dominated by ideas based in technical control, abstraction, and mastery, and in which concepts such as empathetic knowledge and ecological thinking are not well understood.

I turn now to two women composers of the same generation as Pierre Boulez, to analyze their attitudes towards compositional aesthetics. The ideas of Daphne Oram and Pauline Oliveros both contribute to creative thinking on context, abstraction and compositional control. Oram's work has received little attention until quite recently, while the more widely known Oliveros has sometimes appeared isolated in electroacoustic texts.

5 See Arnulf Zweig, “Theodor Lipps." In the Encyclopedia of Philosophy. New York: Macmillan 1967, Vol. 4, pp 485-6, as quoted in Code (1995: 128). 


\section{DAPHNE ORAM}

Daphne Oram was born in 1925, the same year as Boulez. She began working at the $\mathrm{BBC}$ in 1943, where she was trained as a studio engineer, an opportunity available to women because of the war. In 1944, she began experiments in converting graphic information into sound, building her equipment out of old radio components. She tried at this time to convince the $\mathrm{BBC}$ to start an electronic studio, but met with resistance. When electronic equipment first arrived, she moved pieces together each night from different locations to make a studio, disassembling them each morning. Finally, in 1957, the BBC agreed to begin the Radiophonic Workshop, under pressure from the drama (rather than the music) department. In 1958, Oram became one of the founding directors of the workshop, and in October was sent to Brussels for a conference where she came into contact with other experimental composers including Karlheinz Stockhausen.

Oram left the $\mathrm{BBC}$ in order to set up an independent studio at her home in Kent. Here she returned to her experiments with converting graphic information into sound, creating a system she referred to as Oramics. The use of ten parallel tracks of $35 \mathrm{~mm}$. film allowed Oram to specify the characteristics of several sonic parameters simultaneously. She received several Gulbenkian grants to do this work.

In the 1960s, Oram composed music for theatre, ballet, radio, television, and film. ${ }^{6}$ Dedicated to public education, she also produced many concerts in London and Edinburgh, where she discussed electronic music and played examples composed by herself and others. In 1971, she published a book about her work, intended like her concerts to be accessible to a wide audience.

Oram entitled the book An Individual Note of Music, Sound and Electronics, beginning it with a quote from Michel de Montaigne. This French Renaissance writer is considered to be the originator of the personal essay, relying on human experience rather than abstract theory as a basis for writings. The introduction to Oram's book is full of disclaimers: that the book is not to be considered sober or academic, but is just one person's point of view. Despite her disclaimers, the book is very thought-provoking, written in an accessible and often evocative style. Oram finds analogies to explain electronic processes in everyday language. One of these examples seems particularly poignant in light of Oram's experience at the $\mathrm{BBC}$ :

Probably we have all, at some time, felt the frustration of finding ourselves talking on serious, intelligent matters to someone who has his mind absorbed at that moment by insignificant trivialities. If we are sensitive, we can almost feel physically hurt by his inattentiveness ... our own words seem to cruelly rebound and strike back at us. This is just a small illustration of unmatched impedances. ${ }^{7}(1971,118)$

\footnotetext{
6 see Sophie Fuller, The Pandora Guide to Women Composers: Britian and the United States, 1629Present, (London: Harper Collins, 1994), 234.

She defines impedance earlier in the book. "Electrical impedance is the opposition presented by a circuit to a flow of alternating current" (Oram 1972, 117). If the output impedance of one device
} 
Oram discusses the distortion and dissipation of electrical signals by making an analogy with attempted communication between people. In this case, the listener's inattentiveness leads to distortion of the speaker's message and emotional damage to the speaker, just as in an electrical circuit, unmatched impedances can lead to distortion of the signal and damage to the equipment. This allusion to serious thoughts being trivialized by the listener also suggests the intellectual isolation experienced by Oram.

As well as explaining electronic processes, Oram discusses thinking and knowledge in terms of electronics, referring to what she calls "celetal." This is her neologism: "CELE (the reverse of ELEC) ... reminds us of the Greek KELE meaning 'swelling' and, too, of the French verb CELER: 'to hide'-in this case, what lies hidden, and intangible, gradually emerges... it rises into being" (1971, 12). Oram claims that celetal thought brings art and science together in balance, and uses the Taoist yin-yang symbol as an example of this. She rejects the word "control" as inadequate to describe what an electronic composer does with sound, saying that the word she searches for does not exist in the English language:

I am hunting for some word which brings a hint of the skillful yachtsman in fierce mid-Atlantic, guiding and controlling his craft and yet being taken along with it, sensing the best way to manage his vessel, freely changing his mind as unforeseen circumstances evolve, yet always applying his greatest discipline to himself and his seamanship. $(1971,13)$

Here, the emphasis is on self-control, working with natural forces, accepting chance circumstances interacting with personal action. This is not a conceptual dichotomy between composer's concept and sound material: in Oram's sailing analogy, the composer who creates a rigid distinction between his craft and the sound would drown as quickly as a sailor who did not listen to the wind. Oram later discusses the relationship of chance and determinacy through the analogy of taking a car trip down a familiar road, and noting how an experience of the trip changes according to the season, circumstances and time of day, but how similarities in the geography persist from year to year or day to day. The route may stay the same, but the attentive traveller will perceive differences every time. In each case, her thinking reflects interaction with the environment rather than control over it, attentiveness to the surrounding situation, and patience to wait for the intangible to reveal itself. She emphasizes attention to context and an ability to respond to environmental change, all characteristics of ecological thinking.

Oram's book explores many concepts, processes and analogies, ideas that seem to have been developed in relative isolation, as the book title suggests. Although she is aware of the work of electroacoustic composers in Europe and North America (a wide variety of recordings is listed in the Appendix of her book), her biography by Sophie Fuller (1994) exposes her isolation within the

is not matched with a similar input on another, the result is distortion, destruction or dissipation of the signal. 
$\mathrm{BBC}$, and her brief contact with other composers in 1958 at the Brussels conference. Having worked in isolation, Oram then communicated her ideas through a concert series, the book, and in the 1980s through teaching at Christ Church College, Canterbury. Manning notes that Oramics "provides the composer with a specification facility unparalleled in all but the most sophisticated voltagecontrolled systems" $(1985,115)$; still, references to Oram's work are very sparse, and out of a wide range of electroacoustic textbooks that I reviewed (McCartney 2000 ), she was only mentioned in one. Since her death in 2003, some important work has been done to document her life and work, ${ }^{8}$ but the relative lack of attention given her work during her lifetime meant that her important ideas and skills were not disseminated as widely as they ought to have been.

\section{Pauline Oliveros}

Born in 1932, Pauline Oliveros is just a few years younger than Oram and Stockhausen. She began working with electronic improvisation in the fifties, and was a member of the San Francisco Tape Music Center from 1961, becoming its director in 1966. She was also director of the Center for Music Experiment at the University of California in San Diego, where she taught for fourteen years. In the 1970s, she became increasingly interested in Taoism, Buddhism, meditation and feminism. Her Sonic Meditations (1974), created from her experiences of performing with a group of women, are examples of work from this period that involves ritual and intense, meditative listening. In 1981, she moved to New York State and shortly thereafter set up the Oliveros Foundation, a non-profit arts organization. In 1988, she formed the Deep Listening band. This group has recorded performances in locations with interesting acoustics, such as the Fort Worden cistern, an abandoned water tank in Washington State with a 45second reverberation, and Tarpaper Cave, an abandoned Catskill mountain cement quarry in New York State. Much of her work involves people with varying musical backgrounds, and a blurring of distinctions between performers and audience. She is well known for giving concerts and presentations where she listens, and the audience performs. ${ }^{9}$ The Deep Listening Chorus, directed by Oliveros, meets once a month and is open to anyone (Fuller 1994, 227-231). Her foundation has been known as the Deep Listening Institute since 2005.

Oliveros's book, Software for People, was published in 1984 and contains writings from 1963 to 1980 . Three of the articles specifically address feminism, gender and music composition. "And Don't Call Them 'Lady Composers"' (1984, 47-51), is the only one which was published outside of this anthology. Oliveros notes, in a 1994 interview with Fred Maus, that the New York Times asked her in 1970 to write an article on any topic, so she surprised them with this. In this article, she discusses the lack of opportunities for women, the dismissal of work

8 See for instance Jo Hutton, 2003. "Daphne Oram, her life and work," Organised Sound 8(1). 49-56. A CD of her work has been compiled by Hugh Davies.

9 I took part in such a presentation at the Feminist Theory and Music conference, at University of California Riverside, 1995. 
of women composers, and music critics' emphasis on "great" composers (Oliveros and Maus 1994, 174-193).

In "The Contributions of Women As Composers" Oliveros discusses two modes of creativity: active, analytical creativity resulting from cognitive thought, and receptive creativity in which the artist is a channel (1984, 132-137). Refusing the mainstream dichotomy which declares that (masculine) analytical thought and (feminine) intuition are separate and mutually exclusive, Oliveros includes quotes from Mozart and Beethoven which refer to both of these modes of creativity, and notes that scientists also use both modes. She points out that Western society values and develops the analytical mode, and that intuition is left to chance and remains undeveloped. She also notes the relationship of these modes to stereotyped genders. Oliveros then asks a number of questions about working methods of men and women composers, and what methods or conditions might be used to promote and train intuition. This essay was part of a grant application for research which Oliveros intended to base on the musical scores of student composers at the University of California. The research grant was denied.

"Rags and Patches" is the most playful and the most extensive of the three articles (Oliveros 1984, 112-129). It is an embroidered quilt of anecdotes, letters and fables, populated by Alice in Wonderland, Patchwork Girl, Ojo and Scraps in the Land of Oz. Oliveros asks "did you know there are over one hundred species of fish which change sex regularly? (Maybe even willfully)" Her allusion to the sex lives of fish, far from being irrelevant, indicates a desire to imagine possibilities beyond two fixed stereotyped genders, and the dualistic restrictions of hetero-normativity. Her next question is "I wonder what an androgynous musical form would be?" (ibid., 112). At that time, she did not include an answer. But in 1994, she does. Fred Maus asks her if she has had any more thoughts about androgynous music since writing "Rags and Patches," and she responds:

Well, I think it would certainly be in the deep structure of how the music is played and assembled. You can have music as linear process, and music as nonlinear process. And you can also have music that's both. $(1994,185)$

Here, Oliveros seems to locate musical androgyny in the compositional development of processes that are not linear, a claim somewhat similar to Susan McClary's analysis of contemporary American music by Janika Vandervelde (1991).

Oliveros also contests the dichotomy between music as penetration and listening as passive reception, pointing out that "one can receive music but also actively penetrate it, not to mention all the other finer variations" $(1984,113)$. Again, in the 1994 interview she enlarges upon this, pointing out that focussed aural attention is very active. "Rags and Patches" also includes correspondence with people about Oliveros's role as a woman composer. She creates a model representing the integration of identity, role, duty and will, and how these become unbalanced in stereotyped gender roles. At the end of the article is a fable, with gender translation by Oliveros. The fable appears to be Native American in source because of the inclusion of the character Coyote, but no information is 
given in the book as to where it originated. It was sent by Oliveros as a contribution to a women's art festival, in a section called "Letter to a Young Woman Artist":

Dear Feminist Art Program:

Your collective response and personal potential is welcome to a ragged traveller on a patchy road:

Fox was the only living woman. There was no earth. The water was everywhere. "What shall I do?" Fox asked herself. She began to sing in order to find out.

"I would like to meet somebody," she sang to the sky. Then she met Coyote.

"I thought I was going to meet someone," Fox said.

"Where are you going?" Coyote asked.

"I've been wandering all over trying to find someone. I was worried there for a while."

"Well it's better for two people to go together...that's what they always say."

"O.K. but what will we do?"

"I don't know."

"I got it! Let's try to make the world."

"And how are we going to do that?" Coyote asked.

"SING!" said Fox.

This fable seems a mythical version of Code's concept of second persons. If Fox had maintained a traditional epistemology, in which the construction of knowledge is "an independent project, uncontaminated by the influence of testimony, opinion, or hearsay, [by] ...cognitive agents who can know their environments by their own unaided efforts" then she would not have gone looking for someone to sing with, and found Coyote (Code 1991, 71). Or if she had found Coyote, perhaps she would have listened to her song, then incorporated it into her own repertoire, while asserting her difference and her own song's inherent superiority. Instead, it seems that Fox sought an interdependence:

manifesting itself in patterns of reciprocal influence. Shifting configurations of relationships, and constant reassimilations, reinterpretations, reconstructions of person-histories, commonly in dialogue with other "second persons." (Code 1991, 84)

Fox and Coyote are both dog-like, but of different species. Theirs is not a familial relationship, but one which reaches across an inter-species divide, a relationship which is achieved rather than assumed, a friendship. Fox and Coyote 
have some "affinities and shared but not identical histories" (Code 1991, 103). When they meet, and sing, they create a sound that speaks of both of their stories, rubs together the grain of both of their voices, to create a world that expresses their mutual and changed knowledge of it through their meeting. Oliveros encourages artists to find each other across whatever divides them, to create new musical knowledge by putting their voices together, listening and singing. In their letter to her, the organizers of the Feminist Art Program said "your personal vision and achievements have moved us and enriched our development as young women artists. You are a model to us" (quoted in Oliveros 1984, 103). Oliveros includes this fable in her book as a hopeful message of potential musical and cooperative interaction, a parable of possibility.

Because she is better known than many other women composers, Oliveros is able to enrich the development of others. Her work is discussed, if only briefly, in most of the electroacoustic texts. Because she is fairly well known, a younger generation of electroacoustic composers have benefited from reading or hearing her work. Others, especially in North America, have been able to work with her directly through her performances, university courses and workshops.

Even though Oliveros is much better known than many other women composers, it is still a problem that her work is isolated in many music books. There are still far more references in contemporary music texts to male composers' works than to compositions by women, whose aesthetic approaches seem isolated rather than part of a range of approaches. Christine Battersby points out that to be seen as significant within a genre, an author (or composer) has to be seen as:

individual but not unique; exceptional but not isolated, strange, freakish or simply crazy. Sadly, the mythologies of female Otherness still make it extremely difficult for critics (and women themselves) to see women in such ways. A male creator credited with an ouvre that is féminine might still retain his cultural significance while celebrating non-entity; but a female viewed as hysterical and ecstatic has to fight off a much more mundane kind of cultural non-entity. $(1989,145)$

In my research, the work of women is generally shown to be much less widely recognized than that of men, leading to isolation and relative cultural nonentity. In addition, when only one woman composer is selected for significant attention within a comprehensive textbook or recorded anthology, her work is likely to be perceived as emblematic of an essentialized femininity, rather than part of a range of approaches by women composers. The work of Oliveros remains isolated within many electroacoustic texts. While textbooks and recorded anthologies on CD might seem less important as points of access in the age of the internet, these are still some of the main sites where electroacoustic work is documented, analyzed and discussed, making such work more accessible for teaching purposes. Until scholarly websites are given the same academic respect as books and refereed recordings, canonical status for composers will remain linked to citations in these forms, meaning that the demographics of texts and anthologies are still important. 
The present project, In and Out of the Sound Studio, aims to explore the approaches of several composers, artists and producers, in order to discern patterns of similarity as well as differences in aesthetics. While the majority of our project participants were women, we have also included some men, particularly those engaged in considering questions of gender and sexuality in their work.

\section{HildEgARD WESTERKAMP}

Hildegard Westerkamp creates sonic journeys in her compositions that may not be dissimilar to daily life listening journeys-always on the edge between real and processed, real and imagined sounds. In recent years she has conducted soundwalks in many different places around the world, creating contexts for participants to explore how ears and imagination process sonic experiences. She is active on the Board of the World Forum for Acoustic Ecology (WFAE) and until recently was co-editor of Soundscape-The Journal of Acoustic Ecology, a publication of the WFAE. Her website offers detailed information about her various activities in the areas of soundscape composition, acoustic ecology and soundscape studies: <http://www.sfu.ca/ westerka $>.{ }^{10}$

While Westerkamp's biographical note, reproduced above, clearly situates her work as composition, the entry on Westerkamp in the Encyclopedia of Music in Canada implicitly questions her role as a composer:

Westerkamp's most interesting work involves the recording, processing, mixing, and structuring of environmental sounds into a "composition"exploring a different subject, issue or mood. (Bazzana 1992, 1396)

The quotes around the word composition indicate the author's question about whether this is actually composing. Unlike other composers in the volume, there is no list of selected musical works included in the entry, only writings. Is this because of Westerkamp's contextual soundscape approach to composing, which is often misunderstood? Is it because Westerkamp is also active as a soundscape researcher and activist, as a radio and installation artist, as a writer and as a public educator, as well as a composer, blurring the boundaries of that category?

Westerkamp talks of the importance to her work of several supportive colleagues in the World Soundscape Project and at Coop Radio in Vancouver, as well as her encounters with Pauline Oliveros. She was impressed by the breathing environment that Oliveros creates:

When I hear her play the accordion and the way she uses processing in concerts, it is a breathing type of environment, providing a place for the listener to breathe in and for herself ... while she's playing. The way she develops some of the technology is particularly with that in mind. ${ }^{11}$

Westerkamp also began to integrate Oliveros's sonic meditations into her electroacoustic studio teaching, finding that students started to learn how to

${ }^{10}$ From the bio submitted by Westerkamp to the In and Out of the Sound Studio conference in Montreal, July 2005.

${ }^{11}$ Interview with McCartney, 1993. 
equalize and filter with their own bodies, thinking about how to incorporate technology rather than seeing it as an alien structure.

While Oliveros's recent pieces focus on places with interesting acoustics, Westerkamp's work emphasizes places chosen as much for their ecological and social significance as for their acoustics. The soundwalking series was created specifically for Vancouver radio, and focuses on significant locations in the Vancouver area, such as the flight path for the airport, or skid row. Street Music is about street musicians and their craft, rather than a specific location, but is still based in Vancouver. All of these pieces include encounters with people and other inhabitants. Cricket Voice, for instance, is the result of a specific encounter with a cricket in the Zone of Silence, in New Mexico, USA.

Dialogue is particularly important to Westerkamp: "Going on a participatory soundwalk ... means to learn to establish a natural dialogue between the surroundings and ourselves" $(1974,24)$. She speaks of dialogue with other species, or with the echoes of buildings, recognizing and working with an active, responsive environment. Inherent in her idea of dialogue is a critical awareness of her own limited perspective as recordist:

the recordist's position and perspective, the physical, psychological, political and cultural stance shaping the choices when recording. My choices are influenced by an understanding of the sonic environment as an intimate reflection of the social, technological and natural conditions of the area ... this particular microphone, this particular recording presents only one truth about the environment. (Westerkamp 1994, 89-90)

Her ideas about dialogue also include respect for the inhabitants of a place. This respect affects her approach to studio work with sound as well. Much of her work emphasizes juxtaposition, and subtle highlighting and transformations rather than radical manipulation of sounds. In an email conversation with me, Westerkamp explains why:

I do feel that sounds have their own integrity and feel that they need to be treated with a great deal of care. Why would I slow down the cricket's voice but not my daughter's? If the cricket had come from my own garden, had a name and would talk to me every day, would I still be able to slow it down? Would I need to? It did take me two years to dare to compose with that cricket's recording, as it had been such a magical moment of recording, such a gift. I could not just "manipulate" it. It had to be a new sonic discovery journey to retain the level of magic for me. And I remember a moment at which I said "Stop." The journey was beginning to turn into electronic experimentation and the cricket was being obliterated. Same experience with the raven in Beneath the Forest Floor. I tried to make it into a regularly beating drum...it simply wouldn't let me. So I returned to the shape of the original full call, slowed that down and received from it a drum-like sound. It took a whole day to fly off into electronicland and return to the raven call. (Westerkamp 1995)

Westerkamp speaks of letting the raven sound speak for itself, about caring for the cricket sound and not wanting to obliterate it. She wishes to leave these 
sounds recognizable, not to distance them from their roots in the world. She questions her compositional decisions, and wants sounds to retain their complexity, not to be simplified or obscured through her work. Her engagement with the sounds is reflected in her choice of language: the cricket voice was a magical gift, and with the raven sound, she flew. There is a sense in Westerkamp's language here of an interaction with a living, breathing world, where she can learn from ravens and crickets. At the same time, she does not reject studio manipulation of sound:

I like walking the edge between the real sound and the processed sound. On the one hand I want the listener to recognize the source, and thus want to establish a sense of place. But on the other hand I am also fascinated with the processing of sound in the studio...to explore the sound's musical/ acoustic potential in depth.

But I abstract an original sound only to a certain degree and am not actually interested in blurring its original clarity. I transform sound in order to highlight its original contours and meanings. $(1996,20)$

Studio transformation of sound, in Westerkamp's work, is intended not to divorce sound from its context in order to create a different symbolic world or narrative, but rather to emphasize certain aspects of the sound, to enhance the listeners' apprehension of, and their engagement with, the context of the work. Once again, there is a dialogue, this time inside the pieces: between the abstracted sounds that Westerkamp creates, and the original recordings that she listened to. This dialogue is carried into a studio method in which Westerkamp creates a counterpoint between the original recordings that recur over and over again throughout a piece, juxtaposed with sounds that are derived from these recordings.

For Westerkamp, knowing one's place means trying to understand as much as possible about the social, political, ecological and acoustic aspects of a location before creating a piece based on sounds recorded in that place. In order to know a place sonically, she engages in dialogue with other human listeners, and attempts to work in dialogue with inhabitants of other species, through dwelling on the acoustic particularities of their voices. This is somewhat different from Stockhausen's definition of metacollage as the composer's method of balancing mundane and new sounds: because Westerkamp is committed to listening to the material, the balance derives from interesting facets of the mundane transformed into new sounds in dialogue with their sources, rather than new sounds that are thought of as radically different and separate from the mundane.

Westerkamp says: "I hear the soundscape as a language with which places and societies express themselves" $(1996,19)$. Pierre Boulez also speaks of sound as language: "I started from the fact I was thinking and went on to construct a musical language from scratch" (Peyser 1976, 63). But while Boulez talks of himself as the only originator of a musical language based in his own thought, Westerkamp develops hers by engaging in dialogue with the multiple inhabitants of places, through listening to their sounds. 
While Westerkamp cannot know the sounds of a place exactly as she would know a human friend, I hear in her words an intent to understand them in similar terms, with respect and tolerance of difference, a search for affinities, and a disinclination to bend them to her will, however much she was initially tempted. When she flew off to electronicland, Westerkamp approached the raven call in a normatively electrocaoustic fashion: as a sound object, raw material to be transformed into something else that the composer wants as an element in a predetermined composition. When she returns to the raven call and listens to it (because it would not let her make the beat regular: she recognized its agency), then she received a sound that she recognized as drum-like. She maintained her own agency, was still moving to the sound of her own drum, with a beat that resulted from the rhythm inherent in the original call of the raven and the results of her processing. The dialogue in her work between raven as sound object and subject, between recording and processing, between raven and human, creates bridges between these categories that denies them the power of absolute exclusion by playing in the space between.

Westerkamp's dialogic interactions within compositions provide openings for a feminist analysis around ecological thinking and empathetic knowledge. However, she does not refer to her work as feminist, and only rarely deals directly with themes of gender in her compositions (for instance, His Master's Voice, and Moments of Laughter, neither of which has been included on a CD).

Several of the project participants do describe their work as feminist and address gender issues directly in much of their work. One prominent example is electroacoustic composer Wende Bartley.

\section{WENDE BARTLEY}

Wende Bartley is a Toronto based composer writing electroacoustic, vocal and instrumental music in a variety of mediums. She has received numerous awards and grants, and her work is performed internationally and appears on the empreintes DIGITALes label, among others, She recently completed an investigation into "sound as vibrational energy" funded through the Chalmers Program at the Ontario Arts Council. Recent compositions include "The Handless Maiden", for soprano and electroacoustics with libretto by Claudia Dey, "Panagia" for chamber choir and electroacoustics, a series of 8 channel works including the music-driven theatre work for vocalist Fides Krucker entitled "The girl with no door on her mouth", and "Oracle" which is based on recordings created at early goddess temple sites in Greece and Malta.

Bartley was educated at University of Toronto, and then McGill University, where she received an MMus in composition. It was part of Bartley's graduate work that was presented at the In and Out of the Sound Studio conference: "Rising Tides of Generations Lost," which is an important feminist work about the historical silencing of women's voices. Bartley describes it:

This piece intends to create a sense of the female voice, the historical female voice which has been silenced. The piece starts off using whispered vowels, consonants and syllables-fragments from the words 'speaking, unspoken, seen, 
unseen. It continues by making references to the witch burning trials that swept throughout Europe over several centuries, the suffragette era, and then concluding with phrases about memory from an interview with her mother and great aunt.

I got some strong reactions from some of my colleagues. One person was quite upset and said "Why do you have to write music like this?" My support really came from the combination of my friends and a women's group I belonged to outside of McGill. (Interview with author, 1993)

Hannah Bosma (2003) has discussed Wende Bartley's work as unusual in electrovocal practice. The vast majority of electrovocal pieces have a man as composer and a woman's voice as the material. Bartley's position as a woman composer complicates the binary, and more recently she has also used her own voice in some compositions, taking the position of performer as well as composer. While her early vocal works were concerned with the cultural silencing of women's voices in Western history, her early instrumental works explored formal structures based on the spiral image which has been found at many early stone circle and goddess temple sites. This image led her to explore time as radial rather than linear and organising compositional flow through timbral families.

Bartley describes her more recent work as a "process of working co-creatively with the intelligence of nature" (Copeland/Bartley 2004, 22). She speaks of making connections with "devas" or spirit energies of natural and musical forms that she wishes to work with. Bartley also often works collaboratively with other artists, such as in the interdisciplinary theatre work, The Girl with No Door on Her Mouth, based on texts by Anne Carson and performed, produced and co-directed by Fides Krucker. Through this work, Bartley has been able "to deepen [her] historical awareness of how cultural structures and institutions have been created to contain and control both woman's soundmaking and sexuality. The Girl traces the journey of one woman's voice from containment to ecstasy" (Copeland/Bartley, 2004, 23).

Recently, Bartley has also been considering how principles of sound healing can be applied to compositional work. She considers this knowledge of healing principles to be crucial to creative work at this point in history: "The state of imbalance in our world stems from a denial and rejection of the feminine, of the earth, and of the body. Balance will be restored when there is a true meeting and union between the masculine and the feminine. "The Handless Maiden"-a composition for soprano and electroacoustics - was composed through dialogue with the intelligence of sound to create a sonic tapestry of vibrations with the intention of bringing balance and harmony." (Copeland/Bartley 2004, 26). Inspired by the work of visual artist Judy Chicago, Bartley aims to "forge new models of artistic practice that synthesize formal artistic structures with the expression of women's voices." (Copeland/Bartley 2004, 20). Her references to the intelligence of sound resonate with Westerkamp's assertions that sounds have agency that a composer must listen to and respect. Although they are ar- 
ticulated somewhat differently, both approaches imply a search for empathetic knowledge.

Like Bartley, there were other participants who directly address gender issues in much of their work, such as Eveline Boudreau, Victoria Fenner, Michele Anderson, Shona Dietz, and Marian van der Zon. Of all the conference registrants, it was Professor Barry Truax who discussed both sexuality and gender most explicitly in relation to his own compositional work, perhaps because tenure gives him some measure of protection from discrimination in the workplace. When I first did interviews of women electroacoustic composers in the midnineties, one of the participants spoke openly about issues related to sexuality in the interview, but later refused to have these parts of the interview discussed in a research paper, precisely because of this concern about homophobia.

\section{BARRY TRUAX}

Barry Truax is a Professor in both the School of Communication and the School for the Contemporary Arts at Simon Fraser University where he teaches courses in acoustic communication and electroacoustic music. He has worked with the World Soundscape Project, editing its Handbook for Acoustic Ecology, and has published a book Acoustic Communication dealing with all aspects of sound and technology.

As a composer, Truax is best known for his work with the PODX computer music system which he has used for tape solo works and those which combine tape with live performers or computer graphics. A selection of these pieces may be heard on the recording Sequence of Earlier Heaven, and the Compact Discs Digital Soundscapes, Pacific Rim, Song of Songs, Inside, Islands, and Twin Souls, all on the Cambridge Street Records label, as well as the double CD of the opera Powers of Two. In 1991 his work, Riverrun, was awarded the Magisterium at the International Competition of Electroacoustic Music in Bourges, France, a category open only to electroacoustic composers of 20 or more years experience. $\mathrm{He}$ is also the recipient of one of the 1999 Awards for Teaching Excellence at Simon Fraser University. ${ }^{12}$

Barry Truax was one of a small minority of male registrants at the In and Out of the Sound Studio conference, where his video Androgyne, mon amour was screened during an evening concert. As he states above, as a composer he is best known for his work with the PODX computer system. The instrumental bias of many electroacoustic textbooks ${ }^{13}$ means that there is discussion of his development of hardware and software for real-time granular synthesis of sound, but little is said in these general texts about the content and context of his compositional process, his approach to soundscape composition more particularly, or his ideas about context or control.

12 From the bio submitted for the In and Out of the Sound Studio conference.

13 Discussed at length in McCartney 2000. 
Truax's own writing about electroacoustic music has shifted from an earlier "electro-normative" 14 focus on instruments and techniques, ${ }^{15}$ to historical considerations of soundscape composition, ${ }^{16}$ articles about granular synthesis that bring together questions of technique with those of compositional context and complexity $(1994,38-48)$, and more recently an article that deals directly with questions of gender and sexuality in his own musical work (2003, 117-124). In the latter article, Truax speculates about why there is such an absence of erotic themes, and discussion of gender and sexuality issues, in the arena of electroacoustic music. While discussions of gender and especially homosexuality were muted in musicology as a whole until recent decades, this was particularly marked in relation to electroacoustic music, which has remained primarily a male homosocial environment that denies homoeroticism as a defence: "men working together with technology create a homosocial environment, similar to that found in sports and the military, where strict taboos on homosexual activity are enforced and result in expressions of homophobic denial" (Truax 2003, 118).

For Truax, legitimizing alternative voices is crucial to counter the hierarchical restrictions of the electroacoustic compositional environment: "I believe the emergence and legitimation of these alternative voices is the only way to combat the hegemony of technology and its control over our lives" $(2003,119)$. He continues by describing his contextual and homoerotic approach to composition.

Like Westerkamp, Truax was one of the initial members of the World Soundscape Project, and similarly to Westerkamp, Truax emphasizes the importance of context to his musical composition. He describes his work as "contextually based music creation," focusing primarily on soundscape composition and textbased theatre work, which he believes allow context to surface most compellingly through the specificities of environmental sounds and human voices (Truax $2003,118)$. He discusses the composition of several text-sound works, articulating how his use of granulation, textual transformation and transposition contribute to blurring gender boundaries and creating homoerotic compositions.

Truax traces his interest in integrating voice speaking gendered texts into compositional work to when he began working with sampled recorded sounds, particularly through granulation, in the late 1980s. This interest in working with sampled recorded sound itself grew out of a focus on timbral design in composition. Timbre, the texture of sound, is sensuously tactile, and the exploration of timbre can evoke erotic states. Granulation can involve several harmonic streams at different pitches, dwelling in the timbre of the sound. Truax says "A word becomes a prolonged gesture, often with smooth contours and enriched timbre. Its emotional impact is intensified and the listener has more time to

${ }^{14}$ A playful variant on hetero-normative.

15 See for instance Barry Truax, "Composing with real-time granular sound," Perspectives of New Music 28(2), 1990, 120-34; or Barry Truax, "Composing with time-shifted environmental sound," Leonardo Music Journal 2(1), 1992, 37-40.

${ }_{16}$ See Barry Truax "Electroacoustic music and the soundscape: the inner and outer world." In J. Paynter, T. Howell, R. Orton and P. Seymour, editors, Companion to Contemporary Musical Thought, (London: Routledge, 1992 374-98); or "Genres and techniques of soundscape composition as developed at Simon Fraser University," Organised Sound 7(1), 2002, 5-14. 
savour its levels of meaning" $(2003,119)$. Instead of an electro-normative relentless quest for the new, this is a search for deeper meaning through savouring slowness, textural and textual play. As the harmonizing function of granulation shifts voices up and down, gender boundaries are blurred. Truax chooses to work with female contraltos and male counter-tenors, whose singing can also challenge ideas of what masculine and feminine voices sound like.

After becoming established in the electroacoustic community because of his contributions to real-time granulation systems, Barry Truax has been able to shift his writing to reflect his thinking about social and political contexts of contemporary composition, as well as its instruments and materials. His dual position in Communications and Music, as well as his openness to gender issues, has allowed him to support the work of many women and men student composers, at Simon Fraser University.

Most of the participants in our study do not have a tenured institutional position. Many are independent artists who rely on commissions and grants as well as part-time teaching, editing or contract industry work for their income. This is the case with Kathy Kennedy, a sound artist.

\section{Kathy KenNedy}

Kathy Kennedy is a sound artist with a background in classical singing. Her art practice generally involves the voice and issues of interface with technology, often using telephony or radio. She is also involved in community art, and is a founder of the digital media center for women in Canada, Studio XX, as well as the innovative choral group for women, Choeur Maha. Her large scale sonic installation/performances for up to 100 singers and radio, called "sonic choreographies," have been performed internationally including the inauguration of the Vancouver New Public Library and at the Lincoln Center's Out of Doors Series. <http://www.kathykennedy.ca $>.^{17}$

Kathy Kennedy became interested in composition when she was a graduate student in vocal performance, noting that the role of composer garnered more respect than that of performer, and that there was little repertoire that she could sing from the heart. She could not identify with the crazed female characters that populated the operatic canon. She had been trained as a visual artist before doing music, and understood electroacoustic music as a way of finding a spatial articulation for sound structures, using composition skills that she had learned in art school. ${ }^{18}$

When Kennedy considers spatialization of sound, she is not thinking primarily through instrumental metaphors. In the notes to a recent piece, Ballade Orale, Kennedy thinks through the body: "For years I've been thinking about how we experience sound; how to bathe in it, feel it with the entire body, and also how to listen dynamically... What has become of our relationship to physical space in our world where any sound can be transmitted in any place?" (2006).

${ }^{17}$ From the bio submitted to the In and Out of the Sound Studio conference, Montreal, 2005.

18 Interview with author, Montreal, 1993. Interviews were conducted as part of MA research at York University. (McCartney 1994) 
Her work explores the intimacies and distances of voices and the technologies that broadcast them. Many of her works are large-scale performances involving scores of people, using micro-radio, cell phone or other sound technologies to provide intimate links over distance. These are works that enact her belief that "sound is territory," and that are powerful both spatially and politically. Her sonic choreographies lead peaceful but determined singing through public places with political import, such as city hall or the corporate home of provincial hydro. When these soundmakers walk through such a public place, singing together, they disrupt the hierarchies of power through evident pleasure. During one such interaction at Montréal City Hall:

we got all the way up to the second floor before anybody knew that anything was going on, and we got to feel reactions of people on the street looking at us, and workers coming back from lunch break. They'd look at us, and see women, happy, carefree, singing, and you'd see this big smile from them. The security guards at first did not notice our radios .... Then when they saw all the radios, and saw communication and technology, they freaked out. ${ }^{19}$

Kennedy's work can be understood as an enactment of a politics of urban space, engaging with broadcast technology and performance in the public sphere to subvert established hierarchies. ${ }^{20}$ Certainly she is in control of what happens, control of a large number of people moving through a public place, traversing territory through sound and sound as territory. She pokes fun at her own conducting figure in a video of her piece Never/Always in which a hundred singers travelled in choreographed formations at Place des Arts in Montreal: "Look at the little Napoleon!"21 This ironic stance constantly returns attention to the possible hierarchies being called on by a particular role or situation. Her function exceeds that of a general, however. Consider the musical score to Ballade Orale, which was handed to each audience member of a performance-installation: ${ }^{22}$

Choose a specific song with or without words.

Sing this song in a variety of sonic environments and adapt it musically to the changes.

Listen for other songs and try to integrate them.

Choose, sing, listen, integrate, adapt. Not the words of a general, who relies on foot soldiers to follow orders from above without deviation. Here, Kennedy is attempting to establish an aural commons where the inhabitants enact conscious choices, express themselves through melodious sound, pay attention to the spaces that they are moving through and adapt to those environments, listen for the expressions of others and converse with them. The installation-perform-

19 From an interview with the author, 1993.

20 For further discussion, see Ellen Waterman, "Radio Bodies: Discourse, Performance, Resonance," (forthcoming)

${ }^{21}$ At a public presentation of her work during the Radio Without Boundaries conference, Ryerson University, Toronto (New Adventures in Sound Art), May 2006.

${ }^{22}$ See Kathy Kennedy, "Ballade Orale," EContact! Women and Electroacoustics 3 (Montreal: 2006), <http://cec/concordia.ca/econtact/8_2/Kennedy.html>. 
ance is reliant on the expressions of the audience. Kennedy provides the framework upon which the expressions depend, but she does not determine the outcome. The audience is not asked to listen to and learn from the expressions of the anointed artist, but to co-create with her and with each other. This musical approach is consistent with Kennedy's political commitment to community art, specifically feminist groups such as Studio XX and Chœur Maha.

While Hildegard Westerkamp and Barry Truax both refer to their work as composition, Kathy Kennedy identifies as a sound artist. Many of the participants in the In and Out of the Sound Studio project were not as clearly connected with the fine arts. They may speak of their work as sound design, production, recording, or mixing. Outside of the discourses of music and media arts, little is written about the aesthetics of sound work. To what extent is it possible to speak of shared practices among composers, artists, producers and mixers? In writing on the social and political dynamics of music recording studios, production staff were originally discussed as a different group from musicians, separated from them by the window between recording room and control room. ${ }^{23}$ Those who combine functions, like producer-musician Brian Eno, are surrounded by an aura of genius. Albin Zak's recent analysis of music recording acknowledges that studio work is teamwork and "most of the tasks involved in making a record require some measure of artistry," but the contributions of engineers and producers are still limited to a specific chapter $(2001,163)$. Zak says "A mixing engineer can affect a track's arrangement simply by manipulating the equalization and loudness controls on the mixing console" (ibid., 164). Is this simply manipulation? During a discussion about the In and Out of the Sound Studio project at a concert, a composer turned to me in some surprise when I spoke of Shelley Craig's participation. "Isn't she a technician?"

\section{Shelley Craig}

Shelley Craig is a re-recording mixer with a background in classical music. Shelley received her musical training in piano and composition with a Bachelor of Music from University of British Columbia. She continued her studies at McGill University completing a Masters of Music in the Tonemeister (Sound Recording) program. Shelley works mainly as a National Film Board re-recording engineer mixing sound for film and video. She has also taught a Masters Course in Sound for Image at McGill and has given numerous workshops. Working for the National Film Board for the last twenty years, Shelley has mixed the sound for hundreds of films-animation, documentaries, fiction, docu-drama... Among other awards, she has a Genie nomination for her work on Sitting in Limbo by director John Smith. Presently, in addition to working for the National Film Board, Shelley plays the piano accompaniment for her four children who all

${ }^{23}$ See for instance Edward Kealy, "The Real Rock Revolution: Sound Mixers, Social In equality, and the Aesthetics of Popular Music Production," PhD Dissertation, (Northwestern University, 1974); Steve Jones, Rock Formation: Music, Technology, and Mass Communication (Newbury Park, CA: Sage Publications, 1992). 
study string instruments. As a parent, she aims to offer her children the joy of listening and of hearing the art of sounds. ${ }^{24}$

Like many people who work as engineers and mixers, Shelley Craig received her initial academic training in music performance and composition. Even as a child, she had a profound interest in music, and in mixing music with text. At the age of ten, preparing a student project on famous composers, she used a portable turntable to select excerpts of composers' works to be played along with what she had written about them. As a child, she asked her parents for sound gear such as recorders and microphones. Then, when choosing a university program, she was as attracted to math and physics as much as music, but felt she would miss music too much if she chose engineering. Eventually, with the Tonemeister graduate programme, she was able to combine both of her academic interests. ${ }^{25}$

Craig was the only woman in the Tonemeister programme at McGill in 1983, and the first to graduate from the programme. It was a very competitive atmosphere, unnecessarily so in Craig's opinion. Boden Sandstrom, an American music mix engineer, notes that the music mixing environment is also highly competitive, with hazing rituals attuned to filter women out (Sandstrom 2000).

The mix engineer "is in a position of power. This power involves control of the mix and overall sound" (ibid., 293). It is difficult for women to gain access to these power positions, even when they are trained and on site. Both Boden Sandstrom and Shelley Craig reported an experience where a supportive male colleague had to phone in sick and refuse to come to work before a client would allow the woman mixer to handle the job. The huge theatre console of the film re-recording mixer, with its hundreds of inputs, is emblematic of the control she wields over the shape of the final sound mix.

Yet at the same time, Craig speaks of how film sound is always teamwork, with several people working on the soundtrack including sound recordist, editor, music composer, and mixer. The final word is the film director's. So this is not the ultimate control of one artist, but the constrained control and constant negotiation of one contributor within a particular domain taking part in a larger project. Here is a different concern with context. Beyond the context of the composition, of the sound materials involved in it or of the relationship between artist and audience, it is the context of collaboration in a work setting. Unlike in Boulez' formation, in which a scientist is the most important contributor, here the director, the creative instigator of the film, has the last word. The amount of influence that Craig has depends somewhat on the type of film being made, whether it is documentary, feature or animation. With the latter genre, because all of the sound is done in post-production, there is the greatest latitude for the mixer to shape the world of the soundtrack.

With equalizing, reverberation and spatialization of sound, Shelley Craig mixes sound in ways that shape a film soundtrack both subtly and deeply:

24 From the bio submitted to the In and Out of the Sound Studio conference, Montreal, 2005.

25 For more on Shelley Craig's life and work, see Lisa Gasior, 2005. 
Craig recently worked on a film called War Hospital ... The sound design and location recording, done by John Blerot, made Craig's job a pleasure as Blerot's soundscapes were rich and full, having all been recorded on location at the hospital. The opening sequence of this film ... is a good example of the magic that can happen when good sound recording meets good sound editing meets Shelley Craig. The location recordings are not only true to the images on the screen, they represent the time and space of the film and can be listened to, without the images, as a successful soundscape composition. This is in large part due to the spatialization techniques employed by Craig: the feeling of being in that space is actualized. You can hear helicopters up in the sky, off to one side, or the voice of a hospital volunteer calling from behind you, which makes the film more real. ${ }^{26}$

In the sound world of a film, contributions to the final soundtrack are made by the recordist, on location following dialogue, and frequently in recent times going beyond recording room tone to doing sustained and diverse soundscape recordings on site; the various editors who work on dialogue, music, or sound environments; the music composer and finally the re-recording mixer, whose ear for time and space smoothes all these elements together. The success of her work depends on her ability to establish a positive, empathic relation with the director of the film, and to express that relation sonically.

\section{Diane LebœuF}

Diane Lebœuf is president and artistic director of Sonodesign, a sound design, video and new media production company in Montreal. Her sound work for museum exhibits can be heard at the Pointe-à-Callière and $\mathrm{McCord}$ museums in Montreal, Musée de la Civilisation in Québec, and Grosse Île. Sono design also works with the Cirque du Soleil, and produces DVD and multimedia presentations for a number of media corporations.

Diane Lebœuf's work is highly collaborative. She interacts with museum administrators, exhibit designers, performers, engineers, artists, and historians in her sound design of museum exhibits, many of which are on permanent display at the Pointe-à-Callière museum in Montréal, among other places (she has done over 150 museum exhibits).

A museum sound design has several features that are unique. There are often distinct areas within a room that must be designed sonically to feel different from each other, and yet integrate seamlessly with the other locations in the exhibit, allowing visitors to stroll through, having a sense of movement and continuity. Lebœuf must know the place of the museum very well: its technical constraints of equipment and acoustics; the desires of the exhibitor regarding the design of the overall exhibition; the history and aesthetics of the exhibit itself; the type of audience that is likely to visit the exhibit. Taking all of these factors into account, she needs to design several sound environments that cohabit in one room, and that can be entered at any time. The sound works that she makes therefore have

26 See Gasior, 2005. The excerpt discussed here is included on the CD of this Musicworks issue. 
no defined beginning or end, but are conceived of spatially, as long loops that are harmonically, rhythmically and tonally suited to interact with each other.

Another aspect of Diane's work is sound design for virtual exhibits. For instance, in the McCord exhibit, Urban life through two lenses, <http://www. mccordmuseum.qc.cq/urbanlife $>$, she needed to compose historical soundscapes for 34 Montreal locations to accompany photographs taken by William Notman in the nineteenth century. She and her team worked with historians, and studied the photographs, to decide which sounds would be appropriate for each scene. At the same time, she worked with contemporary photographer Andrzej Maciejewski who did photos from the same perspective as Notman, and recorded current soundscapes in these same locations. Now, a visitor to the website can understand more about changes in the Montreal landscape, both aural and visual, by sliding a mouse over each photograph while viewing them.

Diane Lebœuf's business success has depended on her ability to collaborate well with people in an interdisciplinary context, to try to put herself in the place of people who lived in very different places and times, and to make sonic bridges with contemporary experience, in order to animate exhibits for visitors. She speaks of building life-long relationships with clients, and is now in a position to choose who she wishes to have as clients. In the museum administration community, there are many women, who appreciate the way that Lebœuf explains technical concepts to them in ways that they can understand, and listens to their concerns. These empathetic qualities make her work stand out from the rest.

\section{The Role of the Electroacoustic Soundmaker}

In the early days of electroacoustics, soundmakers like Eimert, Stockhausen and Boulez were concerned with the role of the composer, and how that role was being shaped by the practices of electroacoustic technologies. An anxiety echoes through their assertions that the composer must control primordial sound materials, and that he must be objective, technically up-to-date, and scientific.

At that time, Schaeffer's emphasis on listening to sonic materials and contact with a known sound world seemed radical, too radical to last. Oram had an idea about the role of the composer which seemed more fluid and even more subject to chance. The metaphor of the yachtsman includes a requirement of listening to the environment for one's survival, being open to change and reacting to it as quickly as the sailor reacts to the wind. Oliveros includes listening to others as an important part of creative sound work. Her fable brings together actors of different species who listen to each others' ideas, and learn. Westerkamp also includes listening to the actors within a soundscape composition, whether people, crickets or ravens, attempting to learn more about their roles in the sound environment, and paying attention to how the sound can be processed, and what kinds of processing certain sounds resist. Bartley listens for the devas of sound worlds and works collaboratively with performers. Truax advocates being aware of and explicity about one's gender and sexuality, and how they influence contextual composition. Kennedy opens the role of the sound artist into facilitation of a creative experience for wide audiences, who are included in the creation of 
the sound work. Craig integrates her musical, technical and filmic knowledges in a collaborative work environment where she never loses track of the roles of others in relation to her own. Craig also includes her parenting role in her biography, an indication of how she attempts to integrate parts of her life that seem disparate in this professionalized culture. Lebœuf speaks of an approach to soundmaking that takes into account the needs and desires of a wide range of professional collaborators, and allows visitors to move seamlessly through imaginatively created sonic spaces.

What significance can these shifts in ideas about the role of the soundmaker have for the acceptance of electroacoustic genres? One way would be to challenge the myth of the genderless composer. Claire Piché notes that of the winners in the young composers' competition held by the Canadian Electroacoustic Community up until 2005, only one of the many winners has been female (2006). ${ }^{27}$ The judging is done "blind" (or should we say deaf?) since the jury is able to hear each composition but is not given identifying information about the student and emerging composers involved. If the majority of the composers on the jury accept the same ideas about abstraction, compositional control and technical manipulation that Boulez did-and why would they not, given the canonical restrictions of curricula in which the abstract masters dominate and alternative voices are seldom heard or discussed-then the jury will select those works that fit this same mold, thus continuing and reinforcing these ideas. When a wider range of aesthetics is considered throughout the curricula of electroacoustic music, sound art and sound production courses, through listening to and discussing the work of composers, artists, producers, designers and mixers from many different backgrounds and working contexts, the range of what can be considered electroacoustic soundmaking will really open up to an electroacoustic ecology of diversity, and an acceptance of a wide range of approaches to abstraction, control and knowledge, including empathetic knowing and ecological thought.

\section{REFERENCES}

Bartley, Wende. 1989. Ellipsis. Master's thesis, McGill University Music Dept. Battersby, Christine. 1989. Gender and Genius: Towards A Feminist Aesthetics. Bloomington and Indianapolis: Indiana University Press.

Bazzana, Kevin. 1992 "Hildegard Westerkamp." In Encyclopedia of Music in Canada, ed. Helmut Kallmann, Gilles Potvin and Kenneth Winters, 1396. Toronto: University of Toronto Press.

Born, Georgina. 1995. Rationalizing Culture: IRCAM, Boulez, and the Institutionalization of the Musical Avant-Garde. Berkeley: University of California Press.

${ }^{27}$ In the competition held in the fall of 2006, after Pichẻs article was written, there were two more female winners. 
Bosma, Hannah. 2003. "Bodies of evidence, singing cyborgs and other gender issues in electrovocal music." Organised Sound: An international journal of music technology (Gender in Music Technology) 8, no. 1: 5.

Chadabe, Joel. 1997 Electric Sound: The Past and Promise of Electronic Music. Upper Saddle River, NJ: Prentice Hall.

Code, Lorraine. 1991. What Can She Know? Feminist Theory and the Construction of Knowledge. Ithaca, NY: Cornell.

-1995. Rhetorical Spaces: Essays on Gendered Locations. New York: Routledge.

2005 "Ecological naturalism: Epistemic Responsibility and the Politics of Knowledge." Dialogue and Universalism 15, no. 5/6.

Copeland, Darren, and Wende Bartley. 2004. "in tune with co-creation: the musical practice of Wende Bartley." Musicworks 90. Fall. 18-27.

Cott, Johnathan. 1973. Stockhausen: Conversations with the Composer. New York: Simon and Schuster.

Eimert, Herbert and Karlheinz Stockhausen, ed. 1958. die Reihe 1. Bryn Mawr, Pennsylvania: Theodore Presser. English edition.

Fuller, Sophie. 1994. The Pandora Guide to Women Composers: Britain and the United States, 1629-Present. London: Harper Collins.

Gasior, Lisa. 2005. “That's Ms. Shelley Craig-re-recording mixer extraordinaire." Musicworks Magazine 93 (Fall): 32-39.

Haraway, Donna. 1991. "Situated Knowledges." Simians, Cyborgs, and Women: The Reinvention of Nature. New York: Routledge.

Jo Hutton, Jo. 2003. "Daphne Oram, her life and work." Organised Sound: An international journal of music technology (Gender in Music Technology) 8, no.1: 49-56

Jones, Steve. 1992. Rock Formation: Music, Technology, and Mass Communication Newbury Park, CA: Sage Publications.

Kealy, Edward. 1974. The Real Rock Revolution: Sound Mixers, Social In equality, and the Aesthetics of Popular Music Production. PhD diss., Northwestern University.

Kennedy, Kathy. 2006. "Ballade Orale." EContact! 8.2 Women and Electroacoustics 3. Montreal: Canadian Electroacoustic Community. <http://cec. concordia.ca/econtact/8_2/Kennedy.html>

Lloyd, Genevieve. 1984. The Man of Reason: "Male" and "Female" in Western Philosophy. Minneapolis: University of Minnesota Press.

Maconie, Robin. 1976. The Works of Karlheinz Stockhausen. London: Oxford University Press.

Manning, Peter. 1985. Electronic and Computer Music. 1st edition. Oxford: Clarendon Press.

McCartney, Andra. 1994. Creating Worlds for my Music to Exist: How Women Composers of Electroacoustic Music Make Place for their Voices. MA thesis, Music department, York University, Toronto. <http://s171907168. onlinehome.us/andrasound/research/masters.pdf> 
2000 "Soundscape Composition and the Subversion of Electroacoustic Norms," Journal SEAMUS 14, no. 2: 6-24. Published online for EContact! Electroacoustic Histories. (2001). <http://cec.concordia.ca/econtact/ Histories/SoundscapeComposition.htm>

McClary, Susan. 1991. Feminine Endings: Music, Gender and Sexuality. Minneapolis: University of Minnesota Press.

Nattiez, Jean-Jacques, ed. 1993. The Boulez-Cage Correspondence. Translated by Robert Samuels. Cambridge: Cambridge University Press.

Oliveros, Pauline. 1974. Sonic Meditations. Baltimore, MD: Smith. - 1984. Software for People. Baltimore, MD: Smith.

Oliveros, Pauline and Fred Maus. 1994. "A Conversation about Feminism and Music." Perspectives of New Music 32, no. 2: 174-193.

Oram, Daphne. 1971. An Individual Note of Music, Sound and Electronics. Norfolk: Galliard.

Peyser, John. 1976. Boulez. New York: Schirmer.

Piché, Claire. 2006. "Au delà du sexe et de la technologie : les tendances du genre." EContact! Women and Electroacoustics 3. Montréal: Canadian Electroacoustic Community. <http://cec.concordia.ca/econtact/8_2/Piche.html>

Sandstrom, Boden. 2000. "Women Mix Engineers and the Power of Sound." In Music and Gender, ed. Pirkko Moisala and Beverley Diamond, 289-305. Urbana, IL: University of Illinois Press, 2000.

Schaeffer, Pierre. 1967. La Musique concrète. Paris: Presses Universitaires de France.

- 1990. L'ouvre Musicale. France: INA-GRM.

Truax, Barry. 1990. "Composing with real-time granular sound." Perspectives of New Music 28, no. 2: 120-34.

_. 1992a. "Composing with time-shifted environmental sound." Leonardo Music Journal 2, no.1: 37-40.

-1992b. "Electroacoustic music and the soundscape: the inner and outer world." In Companion to Contemporary Musical Thought, ed. J. Paynter, T. Howell, R. Orton and P. Seymour, 374-398. London: Routledge.

- 1994. "Discovering inner complexity: Time-shifting and transposition with a real-time granulation technique." Computer Music Journal 18, no. 2: $38-48$.

. 2002. "Genres and techniques of soundscape composition as developed at Simon Fraser University." Organised Sound 7, no.1: 5-14.

_. 2003. "Homoeroticism and electroacoustic music: absence and personal voice." Organised Sound 8, no.1: 117-124.

Waterman, Ellen. 2006. "Radio Bodies: Discourse, Performance, Resonance." In Radio Territories, ed. B. LaBelle and E. G. Jensen. Los Angeles: Errant Bodies Press. (forthcoming).

Westerkamp, Hildegard. 1974. "Soundwalking." Sound Heritage 3(4): 24. 1994. "The Soundscape On Radio." In Radio Rethink, ed. D. Augaitis and D. Lander, 89-90. Banff, Alberta: Walter Phillips Gallery. 
1995. Personal communication with author, March 26.

1996. Transformations. CD liner notes. Montreal: empreintes DIGITALes.

Zak, Albin. 2001. The Poetics of Rock: Cutting Tracks, Making Records. Berkeley: University of California Press.

Zweig, Arnulf. 1967. "Theodor Lipps." Encyclopedia of Philosophy Vol. 40. 485486. New York: Macmillan.

\section{Abstract}

This article is an exploration of how genres and practices of electroacoustic soundmaking ${ }^{28}$ are gendered, examining processes of gendering in language used in the early dichotomous categorization between musique concrete and elektronische Musik, then thinking about related arguments concerning abstraction, context, and compositional control in the writings of electroacoustic soundmakers including Pierre Schaeffer, Pierre Boulez, Daphne Oram, Pauline Oliveros, and several participants of the In and Out of the Sound Studio project. Analysis of their practices and ideas suggests different ways of conceptualising electroacoustic genres, their related practices, and roles of contemporary electroacoustic soundmakers (composers, artists, producers, mixers, audiences ...), by examining the potentials of the concepts of empathetic knowledge and ecological thinking, advanced by feminist epistemologist Lorraine Code.

\section{RÉSUMÉ}

Cet article est une exploration des rapports sociaux de genre ("genrification") dans les différents types et pratiques de création sonore électroacoustique ${ }^{29}$, étudiant les procédés de "genrification " du niveau de langage utilisé dans les premières catégorisations dichotomiques entre la musique concrète et l'elektronische Musik, puis se penchant sur les arguments apparentés portent sur l'abstraction, le contexte et le contrôle compositionnel que lon retrouve dans les écrits des créateurs électroacoustiques tels Pierre Schaeffer, Pierre Boulez, Daphne Oram, Pauline Oliveros et plusieurs participants du projet Dedans/Dehors du studio. Lanalyse de leurs pratiques et de leurs idées suggère différentes manières de conceptualiser les genres de lélectroacoustique, leurs pratiques connexes et les rôles des créateurs sonores contemporains en électroacoustique (compositeurs, artistes, producteurs, sonorisateurs, auditoires...), en examinant les potentialités des concepts de connaissance compréhensive et de pensée écologique, termes proposés par lépistémologiste féministe Lorraine Code.

${ }^{28}$ I use the term electroacoustic soundmaking rather than composition because not all of the participants in the In and Out of the Studio project identify themselves as composers, but all, including composers, make creative work with sound.

${ }_{29}$ J'utilise le terme de création sonore électroacoustique au lieu de composition car ce ne sont pas tous les participants au projet Dedans/Dehors du studio qui s'identifie comme compositeurs. Par contre, tous, y compris les compositeurs, créent des œuvres sonores. 